\title{
LANGUAGE AND POETIC METRE IN REGILAUL
}

\section{$\underline{\text { Mari Sarv }}$}

\section{Introduction}

The dominant poetic metre in oral folklore depends on the structure of the particular language, especially on its prosody (see, e.g., Korhonen 1994: 77). The present article aims at studying these aspects in poetry in Kalevala metre, a common phenomenon of Baltic Finnic peoples. Besides alliteration and parallelism, another feature characterizing Kalevala metre is a quantitative trochee with specific rules. Due to those specific rules, the Kalevala metre trochee may be referred to as 'trochee' only with reservations, and that applies to the use of the term throughout the article. I have analysed the regularities and idiosyncrasies in the verse structure of regilaulud (Kalevala metre songs) $* 1$ from Kullamaa parish that were recorded in a phase of disintegration or alteration, and I have made an attempt to compare deviations from the classical regivärss with changes in the Estonian language that might have caused them. In Estonian folkloristics, at least, the mutual cumulative effect of the language and the poetic metre on the development of regilaul has not been analysed sufficiently. In various studies and surveys this aspect is referred to, but a thorough explanation is still missing. The present article provides likewise a collection of suppositional connections, only pointing out potential factors. One substantial default of the article is that it nearly fails to discuss a similarly important aspect - the impact of music (alterations of mainly foreign origin) on poetic metre or language, and vice versa.

In order to fill the void that is essential in discerning the regional deviations of regilaul metre, I analysed the verse structure of Kullamaa songs in Hurt's and Eisen's collections that were closer to regilaul, with reference also to their correlation to different metric systems The number of songs from Kullamaa and from neighbouring parishes in Western Estonia is rather small in the Estonian Folklore Archives. On the one hand, this might be explained by the fact that the classical regilaul tradition disappeared or altered comparatively early, and therefore not many folklore collectors visited the region. Another reason may be its geographical distance from research centres. An apparent reason for folklorists to overlook Kullamaa and the neighbouring region regilaul tradition has been the small amount of songs recorded there. I have chosen Kullamaa regilaul for the current analyses because I am compiling the Kullamaa edition of the serial publication Vana Kannel, and thus it was inevitable to study Kullamaa songs as thoroughly as possible. But it should be mentioned that those songs provide an interesting research material in studying the development of regilaul particularly due to their innovative nature. On the other hand, the lack of systematic consistency apparent in a disappearing song tradition may be caused by the lack of tradition control - when those songs were collected, usually the only audience listening to them was the folklore collector.

The objective of the current work is not to describe verses exactly and in detail, but to demonstrate the linguistic circumstances that have moulded regivärss as it appears in Kullamaa songs. In order to understand the alteration process I have also observed the linguistic circumstances during the rise of the classical regilaul form, as that may be considered the 
initial stage in the nucleus of regilaul region (see Tedre 1990: 12) which seems to include also Western Estonia. In general, I have departed from the Baltic-Finnic proto-language as being a corresponding linguistic form to the classical regilaul metre, as far as that could be connected with the time of the evolvement of regilaul; the study of the poetic metre of Kullamaa songs is based on the Estonian language.

\section{Poetic metre and language}

In describing the language of regilaul an important point of departure is the fact that the word and verse forms occurring in the songs - though being performed at one particular moment originate from different stages in the development of the language and of the poetic metre. Thus some scholars argue that the phonetic and prosodic changes occurring in Proto-Finnic created sufficient conditions for the emergence of Kalevala metre (e.g., Korhonen 1994: 8485). Others claim that the trochaic and asyllabic metre of presumably Baltic origin, perhaps merging later on with an earlier Baltic-Finnic poetic metre, conformed into classical Kalevala metre that took into account linguistic peculiarities (e.g. Kuusi 1994: 48, Leino 1994: 68-69). *2 It has often been stated that Kalevala song with its verse metre developed into an optimal means of expression corresponding to the language structure (e.g. Leino 1982: 329). The length and stress of a syllable became fixed as decisive metric characteristics (Leino 1982: 324).

Languages implementing Kalevala metre have changed since the evolvement of this metric system. The abundant archaisms occurring in Estonian regilaul are conditioned by the requirements of the poetic metre, in addition to the traditional consistency. When the language changed, there were attempts to imitate the traditional song form, but it could not help to maintain the whole archaic linguistic system. Consequently, those songs have adopted also more recent linguistic expressions that concur with the reformed linguistic system, which might have caused alterations of the metre in the course of time. The most essential phonetic changes in the Estonian language that have influenced its rhythmic and syllabic structure are the appearance of the distinction between the second and third duration, the disappearance of the short vowel inside and in the end of the word, the disappearance of weak explosives between vowels and of $h$ in successive syllables, and the gemination of consonants (see Eek, Help 1986: 22-31). The singers have composed new lines that, according to their knowledge, have a correct structure and apply relevant linguistic forms. If regivärss does not correspond to the original rules, it might be considered on the one hand as a withdrawal of the tradition, on the other - an alteration of it. Pentti Leino states likewise that the breaking of the metric system caused by phonetic changes may become a new norm which the singers pick up and observe in the lines they compose themselves (Leino 1982: 39).

The general impression is that the obvious dialectic nature of the regilaul language remains in the shadow of the frequent use of older forms (and as could be discerned, for example, from the analysis of the linguistic formulae in Kihnu regilaul, the more recent dialect reforms are not exposed in regilaul (Niit 1997)). It is understandable that in surveys the description of regilaul language is traditionally limited to the listing of older linguistic forms that have disappeared from the speech by the time of documentation of that song tradition, and to the specifying of their use. But one should take into account here the description of line structure 
and how the poetic metrics has adjusted itself to the development of dialects. In the case of Kullamaa songs, which could be regarded as an elaboration of the classical regilaul, I found it essential to study the considerably frequent lessening tendency of archaic forms in connection with line structure.

Taking into account the principle similarity of the formation system of regilaul in a rather wide territory, and the fact that during the period of massive collecting regilaulud were already in the phase of disappearing and altering, a closer observation of the songs from one parish would rather describe their stage of development at the moment of recording instead of exposing the original peculiarity of the region. Whereas the period for collecting regilaulud was quite short if compared to the period of their evolvement, it appears to be difficult, if not impossible, to discern here the various stages of the development on the basis of songs from only one region. Although a number of scholars have claimed that the analysis of the metric dialects and relating them to changes in language history might cast some light on the evolvement process of Kalevala metre (see, e.g., Kuusi 1994: 55), it is my opinion that in case of Kullamaa songs it would likewise rather characterize the more recent development of regilaul in Western Estonia. But one has to admit that there exist only few separate treatises about regilaul poetic metre in Estonia and very little material is sufficiently analysed in order to make more thorough regional generalizations. The only deeper study into regilaul verse structure was made by Walter Anderson, who analysed statistically the syllables in KolgaJaani regilaulud and provided some generalizations (Anderson 1935).

\section{The problems of the evolvement of Kalevala metre}

To enhance the understanding of the reasons for changes in regilaul I herewith take a closer look at the linguistic conditions under which the Kalevala metre evolved. Relying on previous research, Mikko Korhonen claims that languages in which the basic units in the speech rhythm are syllables, favour syllabic metres, whereas languages in which the speech rhythm is dictated by stress maxima, tend towards dynamic metres (Korhonen 1994: 78). In case of accentual metre the rhythm is constructed by the regulated alternation of stressed and unstressed syllables, in durational metre long and short syllables alternate. In Kalevala metre songs and its following forms, though, the above mentioned syllabic qualities appear decisive only in the first syllables of words comprising more than one syllable - unstressed syllables and those with secondary stress, as well as one-syllable words are in neutral position in constructing the metre. Although the stress is rather an automatic characteristic in Baltic-Finnic languages, the stress-quality of the syllable is still a necessary condition in the opposition of the long and short syllable, and therefore its significance in the evolved metric system is justified. About the prosodic changes in the Proto-Baltic-Finnic and the volume of the stress and its means of expression various ideas have been expressed (see, e.g., Eek, Help 1986, Korhonen 1994, Wiik 1995). But the role of word stress in Kalevala metre songs and the means of expressing it are still unclear and not thoroughly studied, because in case of songs, from among the possible means for expressing stress are chosen pitch to serve the melody, and length opposition to serve the metre. 
Mikko Korhonen describes Kalevala metre as syllabic in principle. The location in the line of the syllables bearing the main stress also depends on the length of the syllables. Kalevala metre could thus be called syllabic-dynamic-durational (Korhonen 1994: 78). Whereas in Kalevala metre are actually fixed only the conditions for the optional position of the word stress and not for the regular repeated alternation, Jaak Põldmäe defines Kalevala metre as a syllabic-durational system with partial stress-regulation (Põldmäe 1978: 152). The primary unit constituting rhythm in Baltic-Finnic languages was a disyllabic foot (see Lippus 1995: 68, also Eek, Help 1986: 18), therefore it is natural that the syllabic metre of that language is also based on a trochee comprising disyllabic feet.

The contradiction between the word and metrical stress occurring in Kalevala metre - the short syllable carrying primary stress is located in an unstressed position in the line - has caused amazement and explanations. Explanations provided are: the prosodic significance of the length of the initial syllable in Proto-Baltic-Finnic; for words with different syllable construction was sought optimal implementation; the need for rhythmic variation; and also the avoiding of semantic ambiguity in case the quantity relations cannot be distinguished clearly enough. The latter explanation was presented by Paavo Ravila and it has been closely studied by Pentti Leino who doubts its significance, because he has discerned very few word-pairs that may cause misunderstanding (Leino 1994: 61).

The contradistinction of quantity in the stressed initial syllable was an important prosodic feature of words in Proto-Baltic-Finnic (see, e.g., Lippus 1995: 39) and the prominence of the initial syllable had been reduced in connection with the expansion of the vowel system in subsequent syllables *3 (Korhonen 1994: 81), which enabled to place the syllable with primary stress in an unstressed position in the line, and therefore from the two possible methods of constituting rhythm the quantity alternation was chosen, because, according to Urve Lippus: if a short syllable can be the most prominent stressed syllable, then in song the alternation of long and short elements cannot be tied to the alternation of stressed and unstressed elements (Lippus 1995: 68). Thus the contradistinction of quantity in the initial syllable became important likewise in the distribution of syllables in Kalevala metre songs. The alternation of long and short syllables has been supported by the principle of isochrony, supposedly existing already in the Baltic-Finnic proto-language according to Kalevi Wiik, which declares all disyllabic feet to be of equal length, therefore the short syllable is generally followed by a long syllable and vice versa (Wiik 1995: 84).

Secondly, to the chosen metric system fit considerably well words with various syllabic structures. The tetrasyllabic words, with secondary stress on the third syllable, occur frequently in archaic forms of Kalevala metre songs and agree with trochee nicely. The implementation of tetrasyllabic words with a short initial syllable is enabled by the first foot in the line that can be freely supplied, the so-called "winnowing" phenomenon, $*_{4}$ on the contrary, makes their implementation more difficult. But the basic problem is particularly to find a possibility to apply trisyllabic words, that would have proved complicated in the case of dynamic syllabic metre. Pentti Leino has studied different poetic metres in the Finnish language, and according to him the Kalevala metre manages to apply trisyllabic words better than any other Finnish metre, particularly so trisyllabic words with a short initial syllable, which occur in Kalevala metre lines analysed by Pentti Leino - if compared to trisyllabic words with a long initial syllable - twice as frequently as in a prose text in standard Finnish (Leino 1982: 239244). 


\section{Prosody regularities in Kullamaa regilaul}

I have analysed *5 103 songs (altogether 1486 lines) that were recorded in Kullamaa parish around the turn of the century. The dialect of the region observed is quite close to the standard language in its attitude towards renewal (unlike the dialect of north-eastern coast, for instance, the archaic nature of which has favoured the persistence of regilaul there). Here regilaul has noticeably deviated from the classical poetic metre both in language and in expression. Already while analysing the Western and Northern Estonian folklore collections from the beginning of the previous century, Ingrid Rüütel has ascertained that the percentage of newer folksongs in transitional form was considerably greater in Western Estonia than on the northern coast (Rüütel 1969: 170).

In the analysis I have decomposed compound words into stems - this way the stress correlation that is significant from the point of metrics appears more distinctly, furthermore, the transcription of compound words as one or two words has sometimes been quite arbitrary by folklore collectors. It has also caused the difference in verse-type classification if compared to the results by W. Anderson (Anderson 1935) whose unsevering of components of compound words has been regarded both as a justified decision (Põldmäe 1978: 22) as well as a deficiency (Sadeniemi 1951: 15-16). I have treated syllables that comprise long vowels, as occasion requires, either as two positions (puhu/siis tu/li to/assa) or as one (pühib/tuad ja/ laamib/lauad), with the exception of the last foot where the absence of the second syllable seems to have developed into a norm variant; there is no ground for the supposition that during the performance of the song one would divide the long syllable between positions. I must admit that such decisions are always somewhat arbitrary if sound recordings do not exist, but the potentiality of false guesses is sufficiently small to allow generalizations.

An outstanding renewal that has been recognized also as characterizing songs in transitional form is the frequent use of seven-position lines instead of eight-position lines, i.e. the occurrence of catalectic trochee besides the acatalectic one. Regardless of the opinions that this phenomenon might be caused by a repeated fault in transcription (Viidalepp 1959: 121), its determined place in the development of Estonian folksongs is proven by the frequent occurrence of heptasyllables in songs of transitional form (Rüütel 1969: 15). Among the Kullamaa verses analysed, the percentage of shortened ones is about a fifth. To shorten the lines, often forms closer to common speech are applied instead of traditional poetic ones. The relatively recent nature of the change is demonstrated, in addition to comparative material from other regions, by the fact that the same lines occur both as classical regivärss-like variants with the preserved octoposition, and also as shortened variants (kui mina hakkan laulemaie cf kui mina hakkan laulema), at the same time there may be found forms without apocope or syncope, "restored" by the singer from recent word forms (tuba jääb tühjaks tütardest cf tuba jääb tühjaks tütretesta) and the implementation of various morphological elements (haava kännu ja hallitand cf haava kännu hallikese). It is noteworthy that the shortening has taken place largely at the expense of tetrasyllabic words, although in the total amount of verses the number of disyllabic words at the end of the line is somewhat bigger. Thus the number of line-end words that have shortened, having presumably been tetrasyllabic in original, is $29 \%$, of those having presumably been disyllabic - only $14 \%$. 


\begin{tabular}{|l|l|l|}
\hline $\begin{array}{l}\text { number of } \\
\text { syllables in the } \\
\text { last word }\end{array}$ & $\begin{array}{l}\text { in lines of } \\
\text { standard } \\
\text { length }\end{array}$ & $\begin{array}{l}\text { in the supposedly } \\
\text { original form of } \\
\text { shortened lines }\end{array}$ \\
\hline 2 & 616 & 104 \\
\hline 3 & 155 & 7 \\
\hline 4 & 419 & 173 \\
\hline 5 & 1 & 11 \\
\hline $\begin{array}{l}\text { shortening has } \\
\text { occurred inside } \\
\text { the line }\end{array}$ & & \\
\hline & & \\
\hline
\end{tabular}

Table 1. The distribution of syllables in line-end words in verses of standard length, and in lines restored as original forms of shortened lines (in shortened lines the occurring number of syllables is usually smaller by one).

Often apocope and syncope forms are used. Uncontracted forms (e.g. kauge'elta, palve'elle) are rather usual in the Estonian tradition, in Kullamaa songs they are rare. It seems that the artificial maintenance of uncontracted forms is avoided, in the whole material only seven such forms occur. The last word is shortened by a syllable even in cases where the contemporary language would allow the final syllable to preserve (nud/nd, kene/ke). There are quite a number of lines where eight or more syllables are placed in a heptapositional line. All these occasions demonstrate that such a shortened line has already become a fixed variant of a supposedly correct regivärss. The phenomenon may bear some connections with the choice of melody in performance, but these are not necessary requirements, because hepta- and octopositional lines occur side by side. Shortened lines appear nearly in two thirds of the songs analysed.

Evidently the fact that syncope and apocope forms have become a norm in the end of the line due to its shortening, has also enhanced the renewal of archaisms also in the rest of the line. Somewhat significant should be regarded lines that have shortened by one position, but the shortening has obviously occurred at the expense of a word inside the line (otsi Mardil osada $<$ *otsi Mardile osada; pealt nad kullal kujutud < *pealt nad kullalla kujutud), whereas the original trochee based on quantity alternation has transformed into a dynamic one. One may also suggest that the correlation is the opposite: the transition to dynamic trochee has forced to reject more archaic expressions. In the shortening of an internal word form in the line it is more common that a replacement is found for the empty position, it often being a word of one syllable (hoia poeg ja toida poeg < *hoia poega, toida poega).

In the current analysis I have usually regarded as exterior to the line expletives placed in the beginning of it, most often $j a$, which by form should belong to the end of the previous line, in order to replace a missing syllable. The last, eighth position in line can never be filled with a one-syllable word (Anderson 1935: 188). This strictly observed rule mentioned already earlier has sent the expletives to the beginning of the next line both in transcriptions and apparently in performance, too. In the material analysed such cases occurred altogether about sixty times, 
but one should keep in mind that while transcribing the songs, such words added only as padding might have been omitted. Consequently, the excessive classification of lines as being heptasyllabic is somewhat conditional.

343 lines, that is twenty-three percent, consist of tri- or tetrasyllabic versefeet. Seventy percent of them are multisyllabic only in the first foot (viiskümmend korda viina joodud), which is quite correct according to the rules of classical regivärss, but the remaining thirty percent contain them also further in the line (raudsed sillad rabade pääle). In very few cases it might be justified by the expressional parallelism between the line parts (is a oli laulik, ema oli laulik), though usually not. It is also against the rules of classical regivärss for a fifth of multisyllabic feet to contain words having more than two syllables.

Accelerated words are usually of short duration. The majority of them are verb forms of olema 'to be', panema 'to put' and tulema 'to come', the other large group are personal pronouns. Very rarely the disyllabic forms of the verb olema are distributed to two positions. Often the expletives that are unnecessary by content or excessive are used with the objective to accelerate and enliven the rhythm (Talle mina tapan toore'eksa; vanad aga sõudsid, pead vabisid), or to fill the empty position caused by the shortening of adjacent words (kaks aga karva kõrva ääres). This feature is more characteristic of men's songs (Laugaste 1955: 98). As was the case with shortened feet, the fact that multisyllabic feet are composed even when it would be easy, if not easier, to do without them, shows the acceptance of such feet as normal or sometimes even recommended.

\begin{tabular}{|l|l|l|}
\hline & $\begin{array}{l}\text { dynamic } \\
\text { trochee }\end{array}$ & $\begin{array}{l}\text { quantitative } \\
\text { trochee }\end{array}$ \\
\hline $\begin{array}{l}\text { long syllable with } \\
\text { prominent stress in } \\
\text { the rise of the foot }\end{array}$ & + & + \\
\hline $\begin{array}{l}\text { short syllable with } \\
\text { prominent stress in } \\
\text { the rise of the foot }\end{array}$ & + & \\
\hline $\begin{array}{l}\text { short syllable with } \\
\text { prominent stress in } \\
\text { the fall of the foot }\end{array}$ & - & \\
\hline $\begin{array}{l}\text { long syllable with } \\
\text { prominent stress in } \\
\text { the fall of the foot }\end{array}$ & - & + \\
\hline
\end{tabular}

Table 2. The different options for composing a dynamic and a quantitative trochee

The so-called broken lines (where the short syllable with prominent stress in the fall of the foot causes the divergence between word and metrical stress) that concur with quantity rules, form eight percent of the analysed sample, in addition there are three percent of lines contai- 
ning trisyllabic words which do not concur with the requirements of neither the quantitative nor the dynamic metre. To compare - Matti Sadeniemi has detected about 50\% of broken lines in Karelian and Ingrian Kalevala metre songs (Sadeniemi 1951: 19), 33\% in Virumaa regivärss and 26\% in Kolga-Jaani regivärss (Sadeniemi 1951: 40-41).

Only $57 \%$ of the lines concur with the quantitative trochee of classical Kalevala metre, if shortened lines are regarded as incorrect. If catalectic lines are also regarded as normal, then the percent of lines concurring with quantity rules is 72 , the opposite being respectively $28 \%$. To compare - the proportion of lines not corresponding to quantity rules found in Ingria is 1.8-1.1\%, in Karelia 2.7\%, in Virumaa 12.3\% and still more in Kolga-Jaani (Sadeniemi 1951: 53). On the other hand, in Kullamaa songs $89 \%$ of lines correspond to the rules of dynamic trochee.

Table 3. The distribution of lines according to syllable composition in the observed Kullamaa songs. $\underline{* 6}$

The application of catalectic trochee, the tendency to use accentual metric system, and the modernization of linguistic expression that characterize Kullamaa regilaul, apply also to songs in transitional form. Ingrid Rüütel has described the latter, particularly recruit and war songs that are closer to regilaul, as follows: Recruit and war songs evolved directly from regivärss. They are sometimes in regivärss form, and frequently they are combined with older regivärss songs. But pure Kalevala metre seldom occurs. /.../ Usually there are no dactylotrochaic verses, and the indifference towards the quantity rules has abruptly grown (often the short syllable of prominent stress occurs in the rise of the foot). Quantity correlation is replaced by stress correlation. (Rüütel 1969: 520-521). The metre and poetic rhythm become more varied: the ordinary four-feet acatalectic trochee is often alternated by a catalectic one, presyllables are added, thus composing iambic verses. The archaisms persistent in regivärss disappear from the language of newer folk songs, where contemporary colloquial speech is used. (Rüütel 1969: 14-15).

Although I have discarded distinctly rhymed songs and the peculiarities of rhyme and parallelism (which are equally important features of newer folk songs according to Rüütel) from the present discussion, still one may discern the tendency towards the transitional form in the songs analysed. The previously mentioned characteristics referring to the transitional form occur in the majority of Kullamaa songs, thus it would be wrong to conclude that they are fixed to certain song genres applying the transitional form (I have not studied the problem thoroughly, though). Usually songs fall quite distinctly into the traditionally established types of regilaul, and therefore I would rather think that the elements of transitional form that disseminated relatively early and widely in Western Estonia have become fixed in the regilaul tradition as a whole.

\section{Linguistic motives causing the change of regilaul metre}

It has been frequently stated that as one cause for the withdrawal of the classical Kalevala metre, besides exterior factors, should be undoubtedly regarded the interior development of the language. But such claims have usually remained without concrete and thorough explanations. In the following I shall attempt to demonstrate, relying on the analysis of Kullamaa regilaul, what changes in the prosody of the language might have caused the metric transformations. 
Ingrid Rüütel has mentioned the following factors in the evolvement of the transitional form: transition from the archaic regivärss language to the modern usage (linguistic development had abolished the basis for the regular quantity alternation, it had caused the frequent change of acatalectic verse into catalectic ones and enhanced their wide dissemination, etc.), adherence to men's tradition (this gave rise to energetic and rough performance that brought about regularity in accentual alternation, increase in the tendency towards end-rhyme, and reduction of parallel lines), and the changes in modern social psychology that required more active, direct and dynamic expression (Rüütel 1969: 711).

The disappearance of vowel harmony in the Estonian language, the shift $o>u$ in successive syllables, and the accentual alternation concentrating on the initial syllable make the latter more prominent than it used to be in the Baltic-Finnic proto-language, which has apparently been one factor in the transition to dynamic trochee. Richard Viidalepp (1959: 119) has indicated that the adding of accentual alternation among the distinctive features of the initial syllable, which is partly perceivable as the further differentiation in the correlation of syllable length, has made it more complicated to discern in the Estonian language the length correlation necessary also in the perception of regivärss rhythm. The footly nature of the language that concorded with the alternation of long and short vowels characteristic to regilaul, has likewise altered, and this in turn has caused the change of the rhythm (see Eek, Help 1986: 20-22).

The results of the comparison of syllable duration (Ross, Lehiste 1996: 120-122) in at least one song confirm the hypothesis that duration in regilaul serves exclusively the function of expressing metrical accent, and even in a song where the deviance from quantity rules, which were originally organically connected with the metrical rhythm, is rather frequent. Whereas the opposition of long and short syllables might not reflect similarly in the musical rhythm of regilaul and the actual syllable duration, it has to be concluded that the alternation of long and short syllables apparently transformed in regilaul into a certain positional perceivance. Likewise, Urve Lippus in discussing rhythmic patterns claims that the proportions of the durations are not as important as is the clear distinction between classes of long and short notes (Lippus 1995: 50).

The more frequent occurrence of word-stress performance in Estonian regilaul, in comparison to the Finnish mainly scanning performance, might supposedly be caused also by the increase of the prominence of the initial syllable, which spread also into regilaul. Therefore, that could similarly be regarded as a certain intermediate phase or fosterer in the transition to accentual metric system. But here as well it should be studied more closely to find out at the expense of which means of expression did the prominence increase, and if and how does it relate to the appearance of word-stress in regilaul.

The use of accentual metric system has been regarded as characteristic of Southern Estonian songlore and of songs in transitional form. There is a relatively larger portion of broken lines in Karelian and Ingrian Kalevala metre songs, the same applies also to proverbs and riddles in comparison to the corresponding Estonian material (Kuusi, Tedre 1979: 77, Sadeniemi 1951: 19, 40-41). Pentti Leino has expressed the opinion that to the Estonian regivärss has never applied the rule which would prohibit the location of the short stressed syllable in the rise of the foot (Leino 1994: 71). But in Western Finland and in some places in Karelia also the classical Kalevala metre started to transform in the sixteenth century into the so-called late 
Kalevala metre where any kind of syllables with prominent stress may locate in the rise (Kuusi, Tedre 1979: 70). Regardless of the fact that much less phonetic shifts influencing the syllable structure and stress features of the word has occurred in the Finnish language, if compared to the Estonian language, Pentti Leino still holds them also there as significant factors - besides the impact of the poetry in Germanic languages - in the disappearance of the balance between the language and the metre, and in the transition to accentual metric system (Leino 1982: 324-329).

It is not caused only by the transition to the accentual system and the inconsistency in the use of trisyllabic words, but also by the general shortening of the language, that the proportion of lines of the composition 2222, for instance, is conspicuously great in Estonian songs (in the current material it is $18 \%$, see also Anderson 1935: 207), if compared to the corresponding 8 and $6.7 \%$ in Karelian and Ingrian songs (Sadeniemi 1951: 20-21). A more distinct picture of the correlation between syllable distribution and the poetic metre would be provided if one compared the syllable distribution in words separately in regilaul and in the language in general. It should be logical to suggest, for example, that the increase of one-syllable words, caused by the shortening of the Estonian language, and consequently also the increase of neutral syllables in regivärss, might in turn be a factor in the blurring of the sense of rhythm.

To the motives that moulded the classical form of regivärss - presented in the passage discussing the evolvement conditions of regilaul - and that are more loosely connected with the specific feature of the language, alternatives have been found also in the occasion of accentual system. When the use of broken lines reduced, starting first with hesitations in using lines with trisyllabic words, the more so with a kind of transition to dynamic trochee, the number and application options of trisyllabic words reduced. It is quite clear that if the broken lines remain in minority (in the amount analysed only $8 \%$ ), and the majority of verses may be interpreted as representing both the dynamic and the quantitative trochee (here 64\%), thus also lines that contradict the rules of quantitative trochee need not any longer seem incorrect to the singer's ear. But the syllabic-dynamic trochee does not allow the use of trisyllabic words elsewhere than in front of unstressed one-syllable words, the number of which is considerably smaller in the language. The chance to use more trisyllabic words with long initial syllables is obtained by shortening the lines by one syllable. It is highly natural, because if one uses the contemporary shorter word forms instead of those appearing in regilaul traditionally, there appear two options: either to accept the shortening of the line, or to add completely new words. Often the first option is easier, considering the already established content and word usage of the line. That aspect and the fact that one-syllable words would be inappropriate at the end of the line, i.e. in the eighth position, have apparently been the factors shortening the lines into heptasyllabic ones.

Another additional option for using trisyllabic words in the accentual system and particularly in the case of words starting with a short syllable, the application of which reduced considerably with the reduction of broken verses, is to fit into a foot three or even four syllables. This phenomenon has been initiated by the freedom that concerned only the first foot but later on became gradually applied in all other feet as well. (At the beginning there still existed a precondition that the multisyllabity could not bring along trisyllabic words Anderson 1935: 6). Pentti Leino calls the indulgence of such a method already in the first foot to be the beginning of the development of Kalevala metre towards an asyllabic form, and he regards the latter to be the fatal turn in the withdrawal process of the classical Kalevala metre 
(Leino 1982: 328). The occasional acceleration of versefeet serves also the purpose of varying the rhythm, which has been regarded in the quantitative system as one of the motives for using broken lines.

Despite the preliminary success in innovation, the application of the dynamic trochee in the developments of regilaul has not become systematic either. It has been prohibited by the tradition which has not allowed the abolition or alteration of more stereotype and conventional lines, having therefore caused the diffusion of metric systems. In his monograph about Estonian prosody, Jaak Põldmäe has asserted the existence of metrical mixed types and he has tried to define the purest ones among them (Põldmäe 1978: 154-156). But one has to admit that such versatility has increased the instability in the use of regivärss, thus fostering the disintegration of regilaul alongside with other factors.

\section{Conclusion}

In comparison with the regilaul in classical form, one may detect in Kullamaa songs a certain tendency of development towards the so-called transitional form, whereas linguistically the word forms are closer to the contemporary language of the moment of performance. The adjustment of transitional elements in the regivärss tradition of Western Estonia has likewise modernized the form of regilaul, enabling it to somewhat go along with linguistic innovations. In the issue, the diffusion of prosodic systems caused by it has nevertheless fostered the disappearance of the regilaul tradition alongside with other factors (see, e.g., Jaago 1997: 119).

While describing the language in regilaul, the use of all kinds of previous forms have been enumerated repeatedly. Yet more attention should be drawn to the correlation of linguistic and prosodic changes. We may regard the following phenomena as supporting the linguistic development:

1) the frequent shortening of lines to seven syllables, mainly in the occasion of tetra- or often disyllabic line-end words in connection with apocope or syncope. The uncontracted forms, unnatural for the language during the time of recording, have not been artificially maintained either. The recency of line shortening is indicated by the appearance of the classical octosyllabic variants of the same line together with heptasyllabic ones;

2) the transition from quantitative trochee to accentual trochee, which is partly connected with the increase in the prominence of the initial syllable in the language. The alternatives of the accentual system in distributing words inside a line are somewhat different, and the deficiency in the application options of some word groups has caused the reduction of the existing syllabicity. Nearly half of the songs in Hurt's and Eisen's collections may adhere to both prosodic systems, as they contain only words with an even number of syllables. There exist more lines that concur with the accentual system (89\%) than those that are in accordance with the quantity system of the classical regivärss.

As was mentioned above, in the present article studying connections between the poetic metre of language and of regilaul, several details have not been discussed yet, and there remain also 
wider areas that would require additional research that is related to the current analysis, in order to obtain a more truthful picture of the problem. The significance of several likely linguistic conditions in the development of regivärss that were presented in the article, may evidently remain largely undefined for ever.

translated by Kristin Kuutma

\section{References}

Anderson, Walter 1935. Studien zur Wortsilbenstatistik der Älteren Estnischen Volkslieder. Eesti Rahvaluule Arhiivi Toimetused 2. Tartu.

Eek, Arvo, Help, Toomas 1986. Rütminihked eesti keele kujunemisloos. Preprint KKI-45. Tallinn. Jaago, Tiiu 1997. Regilaulu varasemast kihist Läänemaal. Läänemaa Muuseumi Toimetised I. Haapsalu, pp. 113-120.

Korhonen, Mikko 1994. The Early History of the Kalevala Metre. Songs Beyond the Kalevala. Transformations of Oral Poetry. Studia Fennica Folkloristica 2. Edited by Anna-Leena Siikala \& Sinikka Vakimo. Helsinki, pp. 75-87.

Kuusi, Matti 1994. Questions of the Kalevala Metre. Songs Beyond the Kalevala. Transformations of Oral Poetry. Studia Fennica Folkloristica 2. Edited by Anna-Leena Siikala \& Sinikka Vakimo. Helsinki, pp. 41-55.

Kuusi, Matti, Tedre, Ülo 1979. Regivärsilise ja kalevalamõõdulise laulutraditsiooni vahekorrast. Dialoog üle lahe. Keel ja Kirjandus, no. 2, pp. 70-79.

Laugaste, Eduard 1955. Arhailised jooned eesti rahvalaulude keeles. Tartu Riikliku Ülikooli Toimetised. Vihik 38. Tallinn, pp. 95-142.

Laugaste, Eduard 1977. Eesti rahvaluule. Tallinn.

Lehiste, Ilse 1970. Suprasegmentals. Cambridge, Massachussetts, and London, England.

Leino, Pentti 1982. Kieli, runo ja mitta. Suomalaisen Kirjallisuuden Seuran toimituksia 376,

Pieksämäki.

Leino, Pentti 1994. The Kalevala Metre and its Development. Songs Beyond the Kalevala.

Transformations of Oral Poetry. Studia Fennica Folkloristica 2. Edited by Anna-Leena Siikala \& Sinikka Vakimo. Helsinki, pp. 56-74.

Lippus, Urve 1995. Linear Musical Thinking. A Theory of Musical Thinking and the Runic Song Tradition of Baltic-Finnish Peoples. Studia Musicologica Universitatis Helsingiensis VII. Tallinn. Niit, Ellen 1997. Kihnu rahvalaulude keelest. Vana kannel VII:1. Kihnu regilaulud. Koostanud ja toimetanud Ottilie Kõiva ja Ingrid Rüütel. Tartu, lk. 41-46.

Peegel, Juhan 1954. Eesti vanade rahvalaulude keele morfoloogia. Väitekiri filoloogiateaduste kandidaadi teadusliku kraadi taotlemiseks. Tartu Riikliku Ülikooli Eesti Keele Kateeder. Tartu. (Käsikiri Eesti Rahvaluule Arhiivis)

Peegel, Juhan 1974. Regivärsilise rahvalaulu keelest. Eesti rahvalaulud. Antoloogia. Toimetanud Ülo Tedre, vol. 4. Tallinn, pp. 45-76.

Põldmäe, Jaak 1978. Eesti värsiõpetus. Monograafia. Tallinn.

Ross, Jaan, Lehiste, Ilse 1996. Trade-off between quantity and stress in Estonian folksong performance? Folklore. Electronic Journal of Folklore. Vol. 2. Edited by Mare Kõiva \& Andres Kuperjanov. Tartu, pp. 116-123. (http://haldjas.folklore.ee/folklore/vol2/rosslehi.htm) Rüütel, Ingrid 1969. Eesti uuema rahvalaulu kujunemine. Dissertatsioon filoloogiakandidaadi teadusliku kraadi taotlemiseks. Tartu. (Käsikiri Eesti Rahvaluule Arhiivis) 
Sadeniemi, Matti 1951. Die Metrik des Kalevala-Verses. FF Communications N:o 139. Helsinki. Tedre, Ülo 1990. Regivärsist üldse ja eriti vepsas. XXXIV Kreutzwaldi päevad. Teesid. Tartu, pp. 11-12.

Viidalepp, Richard 1959. Eesti rahvalaulude poeetika ja keel. Eesti rahvaluule ülevaade. Edited by R. Viidalepp. Tallinn, pp. 116-177.

Wiik, Kalevi 1995. The Baltic Sea Prosodic Area Revisited. Itämerensuomalainen kulttuurialue. The Fenno-Baltic Cultural Area. Edited by Seppo Suhonen. Hesinki, pp. 75-90.

\section{Commentaries}

1 Regilaul (pl. regilaulud) - the Estonian academic term for Baltic-Finnic Kalevala metre folksongs, cf. also regivärss 'Kalevala metre verse'. Usually in articles by Estonian scholars discussing regilaul and regivärss in English, those have been previously referred to as 'runo song' and 'runo verse' (runo being the Finnish term for Kalevala poem). As the latter as well as the term 'Kalevala metre verse' appear one-sidedly connected with only the Finnish tradition and the epic Kalevala, although it applies to the Baltic-Finnic song culture in general, the occasional retaining of the vernacular terminology appears justified (Translator's note).

2 The last three articles referred were published as a separate section of the volume Songs Beyond the Kalevala (1994) and they provide a comparatively modern survey of the Kalevala metre studies in Finland.

3 Prominence - the volume of the sound perceived as the combined effect of the sound attributes (length, stress, pitch, timbre) (see Lehiste 1970: 119).

4 The "winnowing" (end weight) phenomenon: longer words tend to occur towards the end of the line and shorter ones at the beginning (Leino 1994: 57).

5 My analyses was greatly enhanced by a macro, created and left attainable for me by A. Krikmann, to whom I am grateful.

6 Some verse characteristics are directly incomparable to the results of some studies due to the increase of shortened lines. 